\title{
Slow Spread of the Aggressive Invader, Microstegium vimineum (Japanese Stiltgrass)
}

\author{
Emily S.J. Rauschert \\ Cleveland State University, e.rauschert@csuohio.edu \\ David A. Mortensen \\ Pennsylvania State University \\ Ottar N. Bjørnstad \\ Pennsylvania State University \\ Andrea N. Nord \\ Pennsylvania State University \\ Nora Peskin \\ Buenos Aires, Argentina
}

Follow this and additional works at: https://engagedscholarship.csuohio.edu/scibges_facpub

Part of the Biology Commons, and the Weed Science Commons

How does access to this work benefit you? Let us know!

Publisher's Statement

The final publication is available at Springer via http://dx.doi.org/10.1007/s10530-009-9463-y

\section{Recommended Citation}

Rauschert ESJ, Mortensen DA, Bjørnstad ON, Nord AN, Peskin N. 2010. Slow spread of the aggressive invader, microstegium vimineum (japanese stiltgrass). Biol Invasions. 12(3):563-79.

This Article is brought to you for free and open access by the Biological, Geological, and Environmental Sciences Department at EngagedScholarship@CSU. It has been accepted for inclusion in Biological, Geological, and Environmental Faculty Publications by an authorized administrator of EngagedScholarship@CSU. For more information, please contact library.es@csuohio.edu. 


\title{
Slow spread of the aggressive invader, Microstegium vimineum (Japanese stiltgrass)
}

\author{
Emily S. J. Rauschert - David A. Mortensen • \\ Ottar N. Bjørnstad • Andrea N. Nord • \\ Nora Peskin
}

\begin{abstract}
Microstegium vimineum (Japanese stiltgrass) is a non-native weed whose rapid invasion threatens native diversity and regeneration in forests. Using data from a 4 year experiment tracking new invasions in different habitats, we developed a spatial model of patch growth, using maximum likelihood techniques to estimate dispersal and population growth parameters. The patches expanded surprisingly slowly: in the final year, the majority of new seedlings were still within $1 \mathrm{~m}$ of the original patch. The influence of habitat was not as strong as anticipated, although patches created in roadside and wet meadow habitats tended to expand more rapidly and had greater reproductive ratios. The long-term
\end{abstract}

\section{Introduction}

It is essential to understand how rapidly propagules of a species spread, and, once present, what the pattern of establishment will be. Local invasive species presence is affected by a combination of species characteristics, propagule pressure and local environmental factors (Lonsdale 1999), and understanding the response to local environments (Marushia and Holt 2006; Shadel and Molofsky 2002; Sutton et al. 2007) can be critical for targeting management.

As no single species is invasive in all environments, some have called for assessing the invasiveness of a particular population before embarking on control methods, many of which can be devastating for an ecosystem (Peskin et al. 2005; Rew et al. 2008). Not just demographic and dispersal rates projections of the patch growth model suggest much slower spread than has typically been observed for $M$. vimineum. The small scale of natural dispersal suggests that human-mediated dispersal, likely influenced by forest road management, is responsible for the rapid spread of this invasive species.

Keywords Microstegium vimineum . Dispersal · Spatial spread - Spread modeling · Maximum likelihood $\cdot$ Habitat variation 
themselves but their elasticities as well can vary in different environments; Buckley et al. (2005) found that Pinus nigra invasion was more sensitive in shrublands to the probability of establishment but in grazed habitats was most sensitive to the severity of grazing. Additional studies that link local demographics with spread will further inform the design and assessment of integrated management.

It is also clear that environments are not static. Biotic interactions such as deer herbivory, in combination with drought, can profoundly restructure the floristic composition of a site (Webster et al. 2008), while large fluxes in soil moisture can alter habitat suitability in ways that influence the likelihood a site is invaded (Davis and Pelsor 2001). Fluctuating resource theory predicts that communities become more invasible when the amount of unused resources increases (Davis et al. 2000), leading to strong temporal variation in the potential of an environment to foster growth of an invasive species.

If environmental factors make some sites more susceptible to invasion, then it is important for managers to understand how seeds of invasives move within and between sites of varying suitability. Targeted management that either impacts spread rates or that actively manages the invasion front can result in successful area-wide pest suppression. For example, the USDA's preventative Slow the Spread project, which attempts to limit the spread of gypsy moth (Lymantria dispar), has reduced the rate of spread by over $50 \%$ in some areas and has been very cost-effective (Sharov et al. 2002). While there is no similar national program for invasive plants, the Ecological Society of America recommends targeting spread rates as one of six major recommendations for invasive species policy (Lodge et al. 2006). Limiting spread may also be more cost-effective than eradication programs (Myers et al. 2000). In this paper we apply maximum likelihood estimation to quantify spread rates of patches initiated in a range of sites. Our modeling approach identifies sites that support "spreader" populations potentially enhancing a managers' ability to identify sites that will support both establishment and spread of this troublesome invasive.

Microstegium vimineum (Trin.) A. Camus (Japanese stiltgrass) is an exotic species of growing concern in the US for both economic and ecological reasons (Tu 2000). It can form dense monocultures which negatively impact native species (Adams et al. 2006; Oswalt et al. 2007) and interfere with forest regeneration (Oswalt et al. 2004). In its invaded ranges, it is typically found on roadsides, riparian areas, floodplains, lawns, pastures, ditches and forest understories (Fairbrothers and Gray 1972; Hunt and Zaremba 1992). Although considered widespread throughout the eastern US (USDA-NRCS 2007), many local areas remain uninvaded (Cole and Weltzin 2004).

In order to study the dynamics of early invasions of M. vimineum, thirty patches were created in 2003 in several habitat types: intact and disturbed forest, unpaved forest roadside and wet meadow. Population densities were surveyed in a spatially explicit manner from 2004 to 2006. In order to quantify the natural spatial spread of $M$. vimineum, we develop spatially explicit models of the spatial expansion of the populations which we parameterize using maximum likelihood techniques. From the data, we estimate the dispersal properties of $M$. vimineum in the different environments, which allows us to understand the implications of these results for spread. We expected rapid spread under most circumstances, particularly in roadside and disturbed forest habitats. We then project the model forward over a period of 20 years to assess the influence of local dynamics and dispersal on spread over a longer period of time. Finally, we examine the interannual variation in the population dynamics in a given patch and discuss the implications for invasion success and potential management.

\section{Materials and methods}

Study species: Microstegium vimineum

Japanese stiltgrass $M$. vimineum is an annual $\mathrm{C} 4$ grass native to Japan, China, India and Nepal (Tu 2000). It was first collected in the US in 1919 near Knoxville, Tennessee (Fairbrothers and Gray 1972), and has since spread rapidly. Seed germination occurs in the spring and seed set in the fall ( $\mathrm{Tu}$ 2000), with between 10 and 1,000 seeds produced per individual (Virginia Department of Conservation and Recreation 2006) and in a dense population seed production can range from 16,000 to 50,000 seeds $/ \mathrm{m}^{2}$ (Williams 1998). Cleistogamous seeds are typically produced in 
the leaf axils whereas chasmogamous seeds are produced in the terminal raceme (Cheplick 2007); there is no evidence to suggest that dispersal distances would be markedly different or that this would have consequences for individual plant fitness. $M$. vimineum is generally gravity dispersed: it has no known adaptations for wind or animal dispersal, although the seeds are light (approximately $0.75 \mathrm{mg}$, Cheplick 2005) and can be carried by water (Mehrhoff 2000). Areas that are frequently disturbed may experience higher spread rates (Marshall and Buckley 2008b).

Microstegium vimineum has two important advantages compared to the native communities it invades. It is extremely shade tolerant with a surprisingly flat photosynthetic light response curve (Horton and Neufeld 1998; Winter et al. 1982) and is able to grow under light conditions as low as $2-8 \%$ full sun (Cheplick 2005), making it very competitive under low light levels (Barden 1987). Additionally, it is thought to be free of natural enemies in its invaded range; to date, there are no published accounts of granivory, herbivory or pathogens of M. vimineum (Cole and Weltzin 2005) and we observed no visual evidence of herbivore damage or pathogen attack during the 4 years of this study.

Once established, $M$. vimineum produces near monocultures that displace native vegetation, interfere with forest regeneration, and may alter soil chemical properties (Hunt and Zaremba 1992; Kourtev et al. 1998). It is ranked as a Category One Invasive Species (the highest ranking) by the USDA Forest Service (Howard 2005). Adams et al. (2006) found that, above a $10 \%$ cover threshold, M. vimineum was negatively related to relative percent native cover. Native woody species density decreases with increasing M. vimineum cover (Oswalt et al. 2007). $M$. vimineum has also been shown to alter soil characteristics such as pH (Ehrenfeld et al. 2001) and microbial function and structure (Kourtev et al. 2002), perhaps in ways that further facilitate its own invasion. Following disturbance of the upper canopy, $M$. vimineum biomass production had a strong negative relationship to mean red oak seedling height and had a significant negative impact on forest regeneration (Oswalt et al. 2004). The combined effect of $M$. vimineum and deer browsing can shift midstory canopy composition and negatively affect subcanopy bird abundance (Baiser et al. 2008).
Field methods

To investigate the establishment and subsequent spread of M. vimineum in different environments, thirty patches were created in the spring of 2003 in the forested ridge above the Russell E. Larson Agricultural Research Farm at Rock Springs, approximately $16 \mathrm{~km}$ southwest of University Park, PA (40.71161N, $77.93067 \mathrm{~W}$ ). This site did not contain any $M$. vimineum prior to the initiation of the experiment; the nearest known infestation was located approximately $5 \mathrm{~km}$ northeast of the study site (B. Jones and M. Booher, personal communication).

This site lies in the ridge-and-valley physiographic province, in the Appalachian Mountains of central Pennsylvania (USA). The intact forest plots are in a second-growth forest dominated by oak (Quercus spp.), hickory (Carya spp.), eastern hemlock (Tsuga canadensis), and white pine (Pinus strobus). Species composition in the disturbed forest plots is similar, but selective logging, as well as disturbances associated with the creation of a nearby irrigation pond, occurred on the site 15-20 years prior to the experiment. In contrast, the intact forest has not been logged in the past $80-100$ years. The wet meadow plots lie in an open wet meadow dominated by sedges (Carex spp.) and goldenrods (Solidago spp.). The soil underlying the intact forest plots is Laidig extremely stony loam, derived from sandstone and siltstone colluvium; disturbed forest and wet meadow plots are Andover very stony loams formed from sandstone, siltstone and shale colluvium; and roadside plots are on Murrill very stony silt loam derived from sandstone colluvium and limestone residuum (Braker 1981). The rainfall experienced in this area varied from year to year: precipitation during the growing season (April-September) was $862 \mathrm{~mm}$ in 2003, $937 \mathrm{~mm}$ in 2004, $251 \mathrm{~mm}$ in 2005, and $440 \mathrm{~mm}$ in 2006 (The Pennsylvania State Climatologist 2007; The Pennsylvania State University Automated Weather Observation System 2007).

Initially, each patch consisted of two adjacent $1 \times 1 \mathrm{~m}$ squares. Prior to planting, one square was lightly disturbed by raking the leaf litter while the other square was left undisturbed; since the differences created by this mild disturbance were ephemeral and did not lead to persistent differences in seedling establishment, disturbed and undisturbed areas were grouped together for this analysis. Seeds 
were collected from Rothrock State Forest, approximately $25 \mathrm{~km}$ northeast of Rock Springs. Three hundred $M$. vimineum seeds were sown evenly in each square, a total of six hundred seeds in a $1 \times 2 \mathrm{~m}$ space, referred to from here on as a patch. This number of seeds was chosen to represent the approximate seed production of a few smaller individuals establishing in a new area (Peskin 2005). Five patches were created in each of six habitat types: disturbed forest with and without understory (DF), intact forest with and without understory (IF), wet meadow (W) and roadside areas (RS; Fig. 1). These six habitat types were reduced to four during the course of the experiment. The intact forest areas chosen to be with and without understory in 2003 were not appreciably different in terms of understory vegetation composition and cover in subsequent years; thus we grouped them together. The disturbed plots with understory were completely overgrown by Rosa multiflora early in the experiment, so no data were collected there in 2005 or 2006. At the termination of the experiment, no $M$. vimineum was found in those areas. The distribution of these habitats in the landscape did not permit blocking; the patches in a given habitat type are all located proximate to each other (Fig. 1).

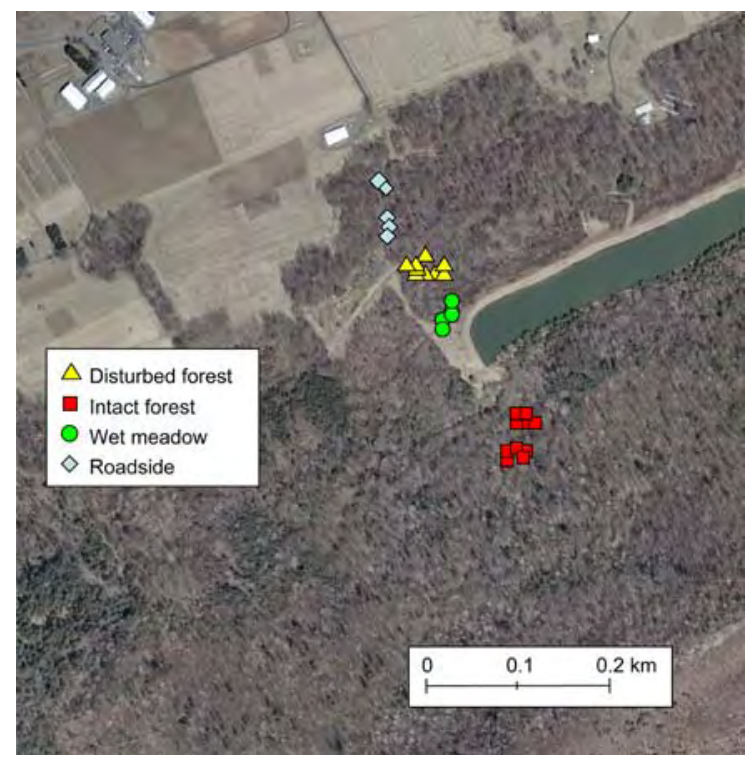

Fig. 1 Map of experimental plots. 30 patches were created in 2003 in four different habitats: intact forest, disturbed forest, wetland and roadside areas. The distribution of potential habitats in the landscape did not permit blocking
Spring seedling germination counts were taken each year in late May or early June. In 2003, the total number of seedlings in the undisturbed and disturbed areas was quantified. Beginning in 2004, more detailed spatial data were taken using a quadrat divided into a grid of $20 \times 20 \mathrm{~cm}$ cells laid over each patch. By the summer of 2004, some of the populations had expanded beyond the initial planting area, and the quadrat was also placed outside the initial patch area to record patch expansion. The entire area surrounding each patch (approximately $10 \mathrm{~m}$ in each direction) was carefully searched for seedlings. The initial patch area $(1 \times 2 \mathrm{~m})$ consisted of 50 cells; after patch expansion, up to 1,247 cells were observed.

A suite of environmental variables were measured in each plot. Soil samples collected in 2004 and 2006 were analyzed for $\mathrm{pH}$, organic matter, ammonium- $\mathrm{N}$, nitrate-N, $\mathrm{P}, \mathrm{K}, \mathrm{Ca}$, and $\mathrm{Mg}$. Soil moisture was measured with an Apogee Quantum Meter LQS 50$3 \mathrm{M}$ soil moisture probe (Apogee Instruments Inc., Roseville, CA) once in the summer of 2006, for the purpose of plot comparisons and not to describe changes through time. Percent cover of all other plant species present in the plots was recorded in 2004 and 2006. Canopy openness was measured in 2003, 2004, and 2005 by analyzing digital photographs taken straight up from the plots with a digital camera (SONY DSC-P8 MPEG Movie VX, focal length 39-117 mm). Canopy cover images were then analyzed with Photoshop CS3 software (version 10.0.1, Adobe Systems Inc., San Jose, CA 2007) to determine percent of view filled by tree canopy. Point measurements of photosynthetically active radiation (PAR) were measured in each plot using a LI-191 Line Quantum Sensor (LI-COR Biosciences, Lincoln, Nebraska). The relationship between seed production, seedling counts and habitat variables is the focus of a companion paper (A. N. Nord et al. in preparation). Following the 2006 seedling count, all patches were terminated by applying sethoxydim, a selective postemergence grass herbicide (Peskin et al. 2005), to begin the multi-year task of eradicating $M$. vimineum at the study site.

\section{Modeling approach}

The modeling approach consisted of a three-step process. We developed a spatially-explicit population model to project the distribution of individuals the 
next year given the current distribution of individuals. This model was first run using initial values for all model parameters. Using the data from the next year, we compared what we had predicted with what was actually observed. We calculated the likelihood of observing the next year's distribution, given the current model and parameters. Optimization algorithms were used to iteratively conduct this process and find the optimal value for the parameters which maximized the likelihood of observing the data given the model.

Spatial model

A spatially-explicit population model was developed following Ribbens et al. (1994) and Humston et al. (2005). This model uses the observed, spatiallyexplicit seedling count in one year to predict the seedling counts in the next year. The number of $M$. vimineum seedlings in a cell $i$ in year $t$ is denoted by $N_{i, t}$. The number of seedlings predicted in a cell $i$ depends on the distribution of seedlings in the previous year, the dispersal kernel $(K)$, and the geometric rate of increase for that year (for annual plants reproducing once a year, this is also equivalent to the reproductive ratio):

$\lambda_{i, t}=\sum_{j=1}^{J} R N_{j, t-1} K\left(\rho_{i, j}\right)$

where $\lambda$ is the expected number of $M$. vimineum seedlings in cell $i$ at time $t$ for $J$ cells observed (up to 1,247 ) in a patch, $\rho$ is the distance between two cells $i$ and $j$, and $R$ is the reproductive ratio.

We assumed simple diffusion, thus the dispersal kernel $(K)$ was taken to have a Gaussian form (Okubo 1980), in which the number of seedlings dispersed to a location decays with the distance from the parental plant according to

$K(\rho)=\frac{\exp \left(-\rho^{2} / D^{2}\right)}{c}$

where $D$ is the diffusion coefficient and $c$ is a normalizing constant.

This model does not explicitly incorporate a seedbank due to co-linearity of parameters, as no explicit data were available on the seedbank. $M$. vimineum has a generally short-lived seedbank (3-5 years; Barden
1987 estimated in North Carolina), and data from previous experiments indicate that in this area seedbank persistence is very low (D. A. Mortensen, unpublished data), perhaps due to the colder climate in Pennsylvania. Ongoing seedbank studies also indicate that germination rates can be extremely high, leaving only a very small proportion of seeds in the seedbank (A. N. Nord, unpublished data).

Maximum likelihood calculation and optimization

We examined the transitions in population sizes in the patches from 2003 to 2006. The reproductive ratios $\left(R_{2004}-R_{2006}\right)$ and diffusion coefficients $(D)$ were estimated from the seedling count data using maximum likelihood techniques to compare the predicted and observed numbers of seedlings in each cell in the following year (Table 1). Due to significantly inflated variances, which occurs commonly in ecological data (Bolker 2008), we used negative binomial rather than Poisson distributions when calculating the likelihood of observing the data. Thus we assumed that

$N_{i, t} \sim$ negative binomial $\left(\lambda_{i, t}, \theta\right)$

where $\theta$ is the negative binomial dispersion parameter, which indicates the degree of overdispersion in the data. We estimated $\theta$ from the data using the method of moments (Venables and Ripley 2002).

Additionally, there was considerable zero inflation, a common problem in ecological data (Martin et al. 2005). The term zero inflation refers to the presence of more zeros than can be well fitted to standard statistical distributions (Heilbron 1994), whether from true zeros or sampling error. It is important to consider the source of excess zeros, in our case, true zeros, in order to choose the correct modeling approach. As suggested by Martin et al. (2005), we used the zero-inflated negative binomial probabilities, as implemented by Bolker (2008). This involved the estimation of a fifth parameter, $z$, the zero-inflation probability. Thus our zero-inflated distribution, with an underlying negative binomial probability distribution can be formulated as:

$$
\begin{aligned}
\text { Probability }\left(N_{i, t}=0\right)= & z+(1-z) \\
& \times \text { negative } \operatorname{binomial}\left(\lambda_{i, t}, \theta\right)
\end{aligned}
$$


Table 1 Model parameters

\begin{tabular}{lll}
\hline Symbol & Parameter & Range \\
\hline$D$ & Gaussian diffusion coefficient & Restricted to positive values \\
$R_{2004}$ & Reproductive ratio between 2003-2004 & Restricted to positive values \\
$R_{2005}$ & Reproductive ratio between 2004-2005 & Restricted to positive values \\
$R_{2006}$ & Reproductive ratio between 2005-2006 & Restricted to positive values \\
$z$ & Zero-inflation parameter & $0-1$
\end{tabular}

These parameters are estimated from the data using maximum likelihood techniques. A reproductive ratio of 1 indicates exact replacement; values higher than 1 indicate growing populations. The higher the zero inflation parameter is, the more zero-inflation is present

$$
\begin{aligned}
\operatorname{Probability}\left(N_{i, t}=0\right)= & (1-z) \\
& \times \text { negative binomial }\left(\lambda_{i, t}, \theta\right)
\end{aligned}
$$

To accommodate the large amounts of interannual variation in population size observed, we calculated different reproductive ratios for each year; the diffusion coefficient and zero-inflation parameters were assumed to be constant throughout the experiment.

Several model parameters needed to be constrained; we chose to constrain parameters by first transforming them. The logit transformation was used to constrain $z$ to between 0 and 1 , and the $\log$ transformation was used to constrain reproductive ratios to be positive. It was not necessary to constrain $D$, the diffusion coefficient, since it is squared in the dispersal kernel calculation, ensuring positive values.

Standard errors were calculated numerically from the Hessian matrix, which contains the second partial derivatives of the likelihood surface with respect to the parameters; the diagonal elements of the inverse Hessian contain the estimated squared standard errors (Bolker 2008). The calculations for some patches resulted in negative diagonal elements in the inverse Hessian matrix, which did not permit the calculation of standard errors.

The model was implemented in $\mathrm{R}$, and optimal parameter values were located using the "optim" function (R Development Core Team 2008). Two optimization algorithms, Nelder-Mead and simulated annealing, were used iteratively by running one algorithm then initiating the other algorithm at the optimal parameter values found by the first algorithm. The model with the lowest Akaike's information criterion (AIC) values was then selected, except in two cases where the Hessian matrix was singular in the model with the lowest AIC value.
Analysis of model results

To investigate whether dispersal and growth model parameters differed between habitat types, we performed a meta-analysis of the habitat parameters. We developed general linear models of the untransformed parameters, weighted by the variances in the parameters, to examine the effect of the habitat classifications. We excluded patches from this analysis for which we could not calculate standard errors, and one patch for which an extremely outlying value for the reproductive ratio from 2005 to 2006 was estimated, leaving a total of 21 plots in the analysis.

In addition to investigating the effect of habitat on the dispersal and reproductive parameters, we also examined the environmental variables measured in each plot. All of the environmental covariates were considered in a meta-analysis of the dispersal and reproductive parameters. Due to correlations in the environmental variables measuring the same parameter in different years, the potential response variables were divided into two groups: variables from the early portion of the experiment (2003 and 2004) and variables measured at the end of the experiment (2006). Additionally, the canopy openness and PAR readings were highly correlated (85\%); thus only canopy openness was retained in the analyses. Best subsets regressions were run using the regsubset function in the leaps package of R (Lumley 2008). Corrected AIC values (AICc) were used for model comparison due to the small number of patches (Burnham and Anderson 2004). Models were fit with both sets of environmental variables, and the set with the better fit was selected for use.

To investigate the implications of the dispersal and reproductive parameters estimated from the data, we examined the model's projected future spatial 
expansion. Analytical solutions to this type of model exist (Androw et al. 1990; Case 2000), with a projected asymptotic annual increase in the radius of the infestation $\left(i_{\text {radius }}\right)$ described by:

$i_{\text {radius }}=2 \sqrt{r D^{\prime}}$

where $r$ is the instantaneous rate of population increase and $D^{\prime}$ is a dispersal parameter related to $D$ according to

$D^{\prime}=\frac{D}{4}$.

$R$, the reproductive ratios calculated, are related to $r$ according to

$r=\ln (R)$

Thus in our case,

$i_{\text {radius }}=\sqrt{\ln (R) D}$

We projected the spatial model 20 years into the future, thereby approximating (liberally) the time this species has had to invade Rothrock State Forest in central Pennsylvania (foresters estimate less than 10 years from appearance to widespread invasion throughout the forest). We examined both the outlier patches as well as the mean of each habitat, and compare the extent of the invasion (the diameter) to the extent of the invaded ranges in Rothrock.

\section{Results}

Microstegium vimineum was present in all plots in all years until the experiment was terminated in 2006 , with the exception of those plots overgrown by $R$. multiflora (5 out of 30 patches). The numbers of seedlings per patch varied considerably among and within habitats (Table 2). Population trajectories varied considerably in time; Fig. 2 shows sample trajectories in different habitats. Some patches appeared to be declining to extirpation after a few years ( 3 of 4 of those patches were found in intact forest sites) while other patches were relatively stable in population density and spatial extent. Several patches experienced explosions in population density and/or spatial extent ( 4 of 5 of those were located in roadside or wet meadow sites); other patches, particularly along roadsides, had satellite populations establish, for example in the middle of the road.
Table 2 Seedling recruitment in each patch

\begin{tabular}{|c|c|c|c|c|}
\hline Patch & 2003 & 2004 & 2005 & 2006 \\
\hline DF1 & 157 & 112 & 82 & 89 \\
\hline DF2 & 87 & 364 & 738 & 85 \\
\hline DF3 & 192 & 209 & 562 & 34 \\
\hline DF4 & 293 & 360 & 354 & 32 \\
\hline DF5 & 232 & 1,731 & 4,075 & 632 \\
\hline IF1 & 244 & 500 & 749 & 375 \\
\hline IF2 & 285 & 481 & 765 & 477 \\
\hline IF3 & 187 & 125 & 128 & 22 \\
\hline IF4 & 259 & 158 & 133 & 31 \\
\hline IF5 & 225 & 258 & 628 & 439 \\
\hline IF6 & 194 & 202 & 243 & 154 \\
\hline IF7 & 233 & 95 & 16 & 7 \\
\hline IF8 & 202 & 256 & 339 & 674 \\
\hline IF9 & 142 & 511 & 1,004 & 4,264 \\
\hline IF10 & 177 & 35 & 46 & 72 \\
\hline W1 & 209 & 435 & 1,062 & 436 \\
\hline W2 & 165 & 198 & 241 & 45 \\
\hline W3 & 195 & 137 & 256 & 464 \\
\hline W4 & 196 & 345 & 1,590 & 3,949 \\
\hline W5 & 79 & 7 & 112 & 2,964 \\
\hline RS1 & 68 & 624 & 1,695 & 2,029 \\
\hline $\mathrm{RS} 2$ & 197 & 371 & 627 & 774 \\
\hline RS3 & 144 & 313 & 1,176 & 742 \\
\hline RS4 & 155 & 527 & 435 & 1,203 \\
\hline RS5 & 54 & 196 & 2,882 & 12,720 \\
\hline
\end{tabular}

Spring seedling counts in each patch were recorded each year. Note that in every habitat type there is at least one patch with rapid population growth

$D F$ disturbed forest, $I F$ intact forest, $R S$ roadside, $W$ wet meadow

Although in general, population counts were highest in the roadside and wet meadow habitats, large populations did establish in a few forested patches as well.

The model parameters estimated from the data are listed in Table 3. The diffusion coefficient, $D$, ranged from 0.18 to $1.86 \mathrm{~m}$ annually, with an average of $0.56 \mathrm{~m}$, implying that most seeds fall within a meter of parent plants. In general, larger values of $D$ were found in roadside and wet meadow patches. The reproductive ratio $(R)$ from 2003 to 2004 ranged from 0.07 to 7.94 , with an average of 1.42 , indicating that most patches were increasing in population density. $R_{2004-2005}$ ranged from 0.17 to 10.9 , with an average 

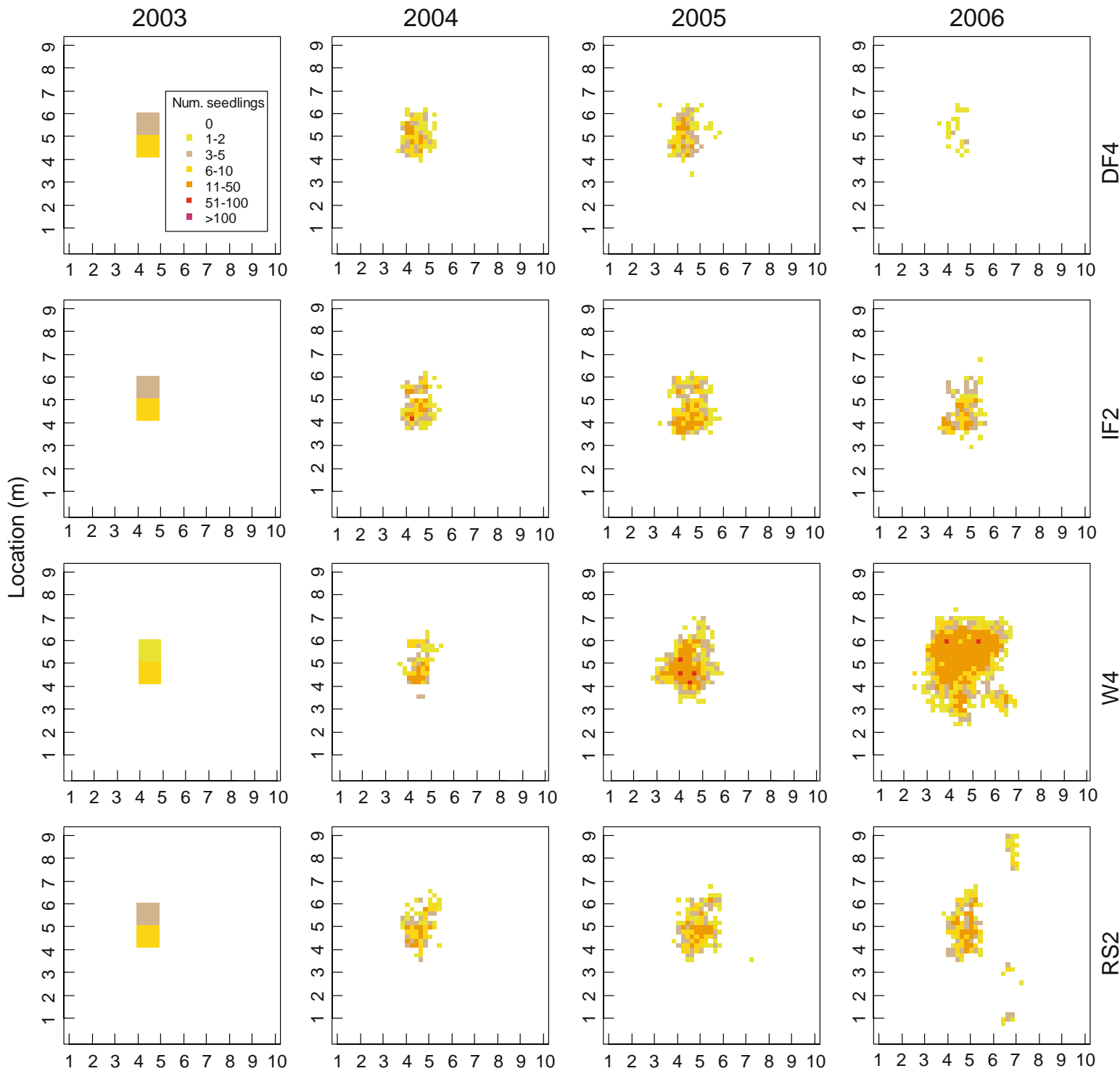

Location (m)

Fig. 2 Sample trajectories of selected patches in different habitat types. The trajectories of four patches from 2003 to 2006 are shown above, where the number of seedlings in each $20 \times 20 \mathrm{~cm}$ cell are represented. The leftmost boxes, from 2003, show the initial plot area. Patches shown were selected to represent the diversity of outcomes in the experiment. The

of 2.30, indicating that in general, populations were growing at a faster rate than during 2003-2004. $R_{2005-2006}$ ranged from 0.12 to 4,905 ; clearly the 4,905 is an outlier. The average reproductive ratio excluding that outlier was 3.21 , again indicating slightly higher growth than in previous years. disturbed forest patch shown actually decreased in both population size and spatial extent while the intact forest patch remained similar in extent and size. The wet meadow patch expanded greatly in size and extent, and the roadside patch led to the establishment of satellite populations in the middle of the road. All data shown in this figure are empirical

The degree of zero-inflation also varied among patches. The range varied from 0 to 0.61 with an average of 0.17 . In many patches, the confidence interval spans the entire range of $z$ (from 0 to 1 ), indicating a high level of uncertainty about $z$. Due to negative values in the diagonal elements of the 
Table 3 Parameter results

\begin{tabular}{|c|c|c|c|c|c|}
\hline Patch & $D$ & $R_{2004}$ & $R_{2005}$ & $R_{2006}$ & $z$ \\
\hline DF1 & $0.47(0.45-0.48)$ & $0.96(0.87-1.07)$ & $2.09(1.65-2.65)$ & $3.39(2.98-3.85)$ & $0.61(0.58-0.65)$ \\
\hline DF2 & $0.27(0.27-0.28)$ & $2.39(2.15-2.66)$ & $0.58(0.54-0.62)$ & $0.12(0.1-0.13)$ & $0(0-1)$ \\
\hline DF3 & $0.3(0.3-0.31)$ & $1.1(1.02-1.19)$ & $2.75(2.52-3.01)$ & $0.26(0.25-0.28)$ & $0.01(0-0.79)$ \\
\hline DF4 & $0.36(0.36-0.36)$ & $1.4(1.32-1.48)$ & $1.12(1.04-1.2)$ & $0.12(0.1-0.14)$ & $0.22(0.17-0.26)$ \\
\hline DF5 & $0.55(0.55-0.55)$ & $7.94(7.4-8.52)$ & $1.41(1.34-1.48)$ & $0.19(0.18-0.19)$ & $0.23(0.2-0.25)$ \\
\hline IF1 & 0.36 (NA) & 4.63 (NA) & $1.3(1.27-1.33)$ & $0.55(0.52-0.58)$ & $0.11(0.08-0.16)$ \\
\hline IF2 & $0.34(0.34-0.34)$ & $0.43(0.4-0.47)$ & $0.77(0.73-0.82)$ & $0.58(0.54-0.63)$ & $0(0-1)$ \\
\hline IF3 & $0.43(0.42-0.45)$ & $1.06(0.96-1.17)$ & $2.31(1.95-2.73)$ & $0.32(0.25-0.41)$ & $0.43(0.38-0.48)$ \\
\hline IF4 & $0.28(0.28-0.29)$ & $0.6(0.55-0.66)$ & $2.41(2.22-2.62)$ & $0.63(0.59-0.68)$ & $0(0-1)$ \\
\hline IF5 & $0.61(0.59-0.63)$ & $0.35(0.32-0.38)$ & $4.14(3.32-5.15)$ & $0.33(0.31-0.36)$ & $0(0-1)$ \\
\hline IF6 & $0.32(0.32-0.32)$ & $0.36(0.33-0.38)$ & $1.56(1.42-1.72)$ & $0.88(0.8-0.97)$ & $0.24(0.2-0.3)$ \\
\hline IF7 & 0.18 (NA) & 0.53 (NA) & $0.17(0.13-0.22)$ & $0.44(0.3-0.64)$ & $0(0-1)$ \\
\hline IF8 & $0.33(0.33-0.33)$ & $1.5(1.4-1.6)$ & $1.69(1.56-1.84)$ & $0.47(0.43-0.51)$ & $0.16(0.12-0.21)$ \\
\hline IF9 & $0.49(0.48-0.51)$ & $0.62(0.57-0.68)$ & $0.69(0.64-0.75)$ & $7.91(6.46-9.7)$ & $0(0-1)$ \\
\hline IF10 & 0.46 (NA) & $0.39(0.31-0.5)$ & 1.6 (NA) & $2.22(1.92-2.58)$ & $0.61(0.56-0.67)$ \\
\hline W1 & $0.62(0.61-0.63)$ & $3.18(3.02-3.35)$ & $1.02(0.95-1.1)$ & $0.63(0.57-0.7)$ & $0.35(0.32-0.38)$ \\
\hline W2 & $0.49(0.48-0.5)$ & $1.87(1.73-2.02)$ & $2.1(1.85-2.39)$ & $0.42(0.35-0.5)$ & $0.51(0.47-0.56)$ \\
\hline W3 & $0.49(0.47-0.5)$ & $1.12(1.01-1.23)$ & $4.76(4.08-5.55)$ & $2.32(2.21-2.44)$ & $0.33(0.3-0.37)$ \\
\hline W4 & $0.99(0.97-1.01)$ & $0.4(0.36-0.43)$ & $1.44(1.37-1.53)$ & $4.08(3.74-4.46)$ & $0(0-1)$ \\
\hline W5 & $1.22(1.19-1.26)$ & $0.07(0.05-0.11)$ & $6.34(5.58-7.2)$ & $28.1(24.2-32.5)$ & $0(0-1)$ \\
\hline RS1 & $0.59(0.57-0.6)$ & $3.19(2.96-3.43)$ & $0.64(0.6-0.69)$ & $1.35(1.12-1.62)$ & $0(0-1)$ \\
\hline $\mathrm{RS} 2$ & $0.95(0.94-0.96)$ & $0.47(0.44-0.51)$ & $1.06(0.95-1.18)$ & $4,905(3,782-6,362)$ & $0(0-1)$ \\
\hline RS3 & $1.86(1.81-1.91)$ & $0.98(0.87-1.09)$ & $5.94(5.04-7)$ & $0.82(0.73-0.92)$ & $0.25(0.15-0.38)$ \\
\hline RS4 & $0.4(0.4-0.41)$ & $0.58(0.53-0.62)$ & $0.72(0.67-0.78)$ & $3.38(3.15-3.62)$ & $0(0-1)$ \\
\hline RS5 & $0.96(0.93-0.98)$ & $0.81(0.72-0.91)$ & $10.9(10.1-11.7)$ & $15.4(13.9-17.0)$ & $0(0-1)$ \\
\hline
\end{tabular}

The model parameter values listed; values in parenthesis are plus or minus a standard error. Due to transformation of dispersal and zero inflation parameters, the parameter value estimated is not necessarily in the midpoint of the plus or minus standard error range. Note that in several cases (i.e., patches IF1, IF7, and IF10), it was not possible to calculate standard errors due to negative values in the inverse Hessian matrix

inverse Hessian matrices, it was not always possible to calculate confidence intervals for parameters in all patches.

The variation in the parameters estimated by the model generally was not well explained by the habitat classifications (Table 4; Fig. 3). The boxplots indicate that while the roadside had the highest mean value for the diffusion coefficient, it also had the largest amount of variation. The model for the diffusion coefficient did not indicate that any of the other habitats were significantly different from the disturbed forest habitat, although there was a tendency for the wet meadow habitats to have higher values of $D$. The reproductive ratios from 2003 to 2004 were significantly lower in the intact forest than in the disturbed forests. It appeared that in 20052006, the highest reproductive ratios were seen in the roadsides, followed by wet meadow, then intact forest and finally by disturbed forest habitats. It seems that there may be less zero-inflation in the roadside patches.

The dispersal parameter tended to be smaller in environments with more graminoids and more canopy cover (Table 5). Reproductive parameters were negatively related to soil moisture $\left(R_{2003-2004}\right.$ and $\left.R_{2004-2005}\right)$ and canopy cover $\left(R_{2004-2005}\right.$ and $R_{2005-2006}$ ). Soil nutrients (ammonium, phosphorus and calcium) were generally positively related to reproductive ratios. Higher soil $\mathrm{pH}$ was associated with higher reproductive ratios for 2005-2006. 
Fig. 3 Model parameter results by habitat type. The model parameters estimated from the data were analyzed by habitat type. Box and whisker plot are shown for the dispersal and reproductive ratio parameters, clearly showing the variation within the habitat types. The roadside and wetland habitats had particularly large variation in parameter estimates for the different patches. Patches IF1, IF7, IF10 and RS2 were excluded from this analysis
D

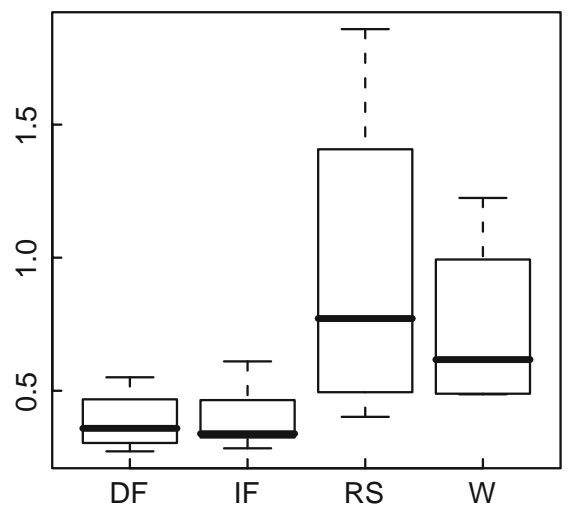

R2005

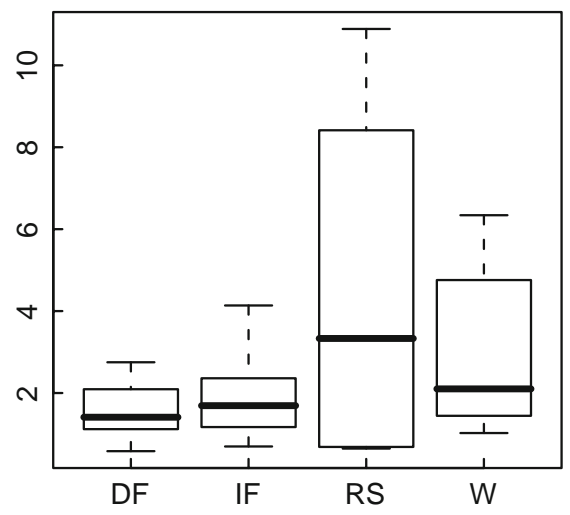

R2004

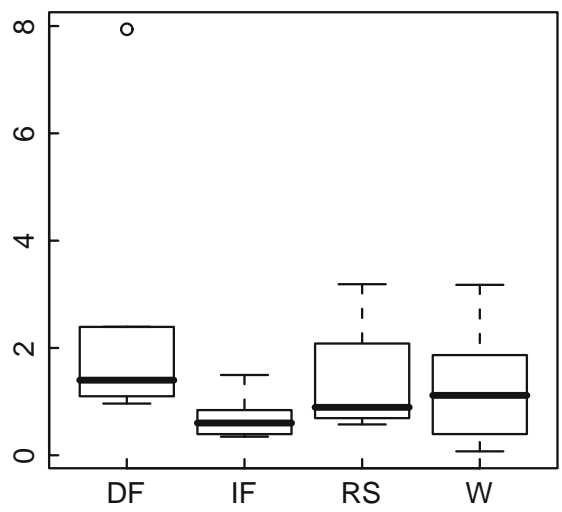

R2006

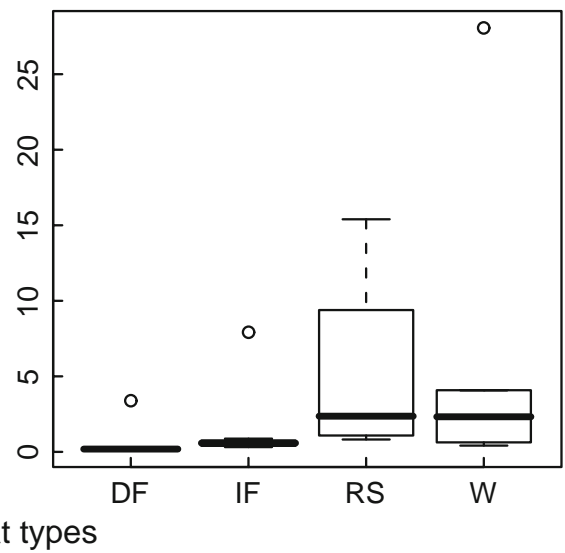

Vegetative cover was positively related to $R_{2004-2005}$ but slightly negatively related to $R_{2005-2006}$. In all cases, the best fitting models were using measurements taken earlier in the experiment.

The model performed well for most patches which expanded uniformly. Figure 4 shows model projections and actual observed values for several selected patches. The correlation between the model projection for a cell and the observed seedling count in the subsequent year was on average 0.63 in 2004 (range $0.16-0.87$ for the patches), 0.63 in 2005 (range 0.150.84 ) and 0.57 in 2006 (range 0.08-0.77). The lower panels of Fig. 4 show instances where this type of model is not able to adequately describe the dynamics of the population. For example, in patches W5 and RS2, the expansion was not uniform in space. Patch W5 expanded anisotropically, and patch RS2 led to the establishment of two satellite populations. In both cases, the model likely overestimated the diffusion coefficient and possibly the reproductive ratio in order to accommodate the observed, non-diffusive expansion.

The projections of the model using parameters estimated for the patches predict very slow invasion. Even in the worst outlier patch (dispersal parameter of 1.86 and reproductive ratio of 4,909), the diameter of the invaded area is a modest $159 \mathrm{~m}$. On average, after twenty years, we would expect the diameter of an invasion in a disturbed forest to be $18 \mathrm{~m}$, an intact forest to be $14 \mathrm{~m}$, a wetland area to be $41 \mathrm{~m}$ and a roadside to be $94 \mathrm{~m}$. For comparison, the extent of the Rothrock invasion after 10 years encompasses a rectangular forest area that is approximately $45 \mathrm{~km}$ long and between 2.5 and $17 \mathrm{~km}$ wide.

\section{Discussion}

This 4 year experiment of invasion in different habitats shows many of the challenges of dealing 
Table 4 Meta-analysis of model parameters and habitat classifications

\begin{tabular}{|c|c|c|c|}
\hline Parameter & Habitat & Estimate & $P$ value \\
\hline$D$ & (Intercept) & 0.38 & \\
\hline \multirow[t]{3}{*}{ (model $P$ value: 0.13 ) } & Intact forest & -0.056 & 0.20 \\
\hline & Roadside & 0.055 & 0.52 \\
\hline & $\begin{array}{l}\text { Wet } \\
\text { meadow }\end{array}$ & 0.23 & 0.11 \\
\hline \multirow{4}{*}{$\begin{array}{l}R_{2004} \\
\text { (model } P \text { value: } 0.03 \text { ) }\end{array}$} & (Intercept) & 0.83 & \\
\hline & Intact forest & -1.14 & $0.00 * *$ \\
\hline & Roadside & -1.29 & $0.08 * * *$ \\
\hline & $\begin{array}{l}\text { Wet } \\
\text { meadow }\end{array}$ & -0.37 & 0.75 \\
\hline \multirow{4}{*}{$\begin{array}{l}R_{2005} \\
\text { (model } P \text { value: } 0.35 \text { ) }\end{array}$} & (Intercept) & 0.19 & \\
\hline & Intact forest & 0.25 & 0.27 \\
\hline & Roadside & -0.43 & 0.32 \\
\hline & $\begin{array}{l}\text { Wet } \\
\text { meadow }\end{array}$ & 0.41 & 0.57 \\
\hline \multirow{4}{*}{$\begin{array}{l}R_{2006} \\
\text { (model } P \text { value: } \\
0.0000010^{* *} \text { ) }\end{array}$} & (Intercept) & -1.9 & \\
\hline & Intact forest & 1.4 & $0.00 * *$ \\
\hline & Roadside & 3.1 & $0.00 * *$ \\
\hline & $\begin{array}{l}\text { Wet } \\
\text { meadow }\end{array}$ & 1.8 & $0.02 *$ \\
\hline \multirow{4}{*}{$\begin{array}{l}z \\
(\text { model } P \text { value: } 0.38)\end{array}$} & (Intercept) & -4.3 & \\
\hline & Intact forest & -2.1 & 0.51 \\
\hline & Roadside & -11 & $0.10 * * *$ \\
\hline & $\begin{array}{l}\text { Wet } \\
\text { meadow }\end{array}$ & 2.5 & 0.91 \\
\hline
\end{tabular}

The results of the analysis of parameters by habitat are described. Note that all habitats are compared to the disturbed forest habitat. Patches IF1, IF7 and IF10 were excluded from the analysis due to a lack of standard errors (leaving 7/10 intact forest patches in the analysis), and patch RS2 was excluded because the estimate for $R_{2006}$ is an outlier (leaving $4 / 5$ roadside patches in the analysis)

* Significance of $P \leq 0.05$

** Significance of $P \leq 0.01$

*** Marginal significance $(P \leq 0.10)$

with invasive species. Through modeling of the spread of M. vimineum, we were able to see how variable spread can be, even within a habitat type. Population trajectories changed in many cases, making it difficult to draw conclusions about the threat of a population at any given point in time. Finally, the slow dispersal rates observed make it clear that factors other than natural dispersal are critical in the spread of this species.

One of the most intriguing results of this analysis was how limited natural dispersal was in the patches.
Approximately $67 \%$ of seeds land within one dispersion coefficient $(D)$ of a parent plant, and $95 \%$ of seeds land within $2 \times D$. While different patches had different estimates of $D$, the range was rather smallthe largest estimate of $D$ was $1.86 \mathrm{~m}$, which implies that even in the fastest spreading patches, $95 \%$ of seeds were deposited within $3.7 \mathrm{~m}$ of parental plants. This is in agreement with Huebner's (2007) study involving seed traps to quantify $M$. vimineum movement, which did not find any seeds beyond $1.5 \mathrm{~m}$. These dispersal distances are very modest for a species that is known to rapidly invade large areas. For the invasive grass Molina caerulea, Jacquemyn et al. (2005) report an invasion speed ranging from 0.2291 to $0.8502 \mathrm{~m} /$ year.

While the apparent short seed dispersal is perhaps not surprising for a mainly gravity-dispersed species, it is in stark contrast to larger-scale spread rates that have been observed. For example, state foresters at Rothrock State Forest in Pennsylvania indicate M. vimineum was first documented in these forest tracts in the mid 1990's (Doug Alm, personal communication); however, it is now widely distributed throughout the forest. This implies that it moves a few kilometers per year, not a few meters per year. Even in the most vigorously growing patches, the diameter of the infestation expected after 20 years is still more than an order of magnitude too small to account for the observed large-scale infestation. Interestingly, a similar discordance between the natural dispersal kernel and the invasion speed has been documented in the large-scale spread of the gypsy moth across the US (Liebhold et al. 1992), testifying to the importance of anthropogenic vectoring.

This experiment was designed to examine whether differences in habitat led to different invasion trajectories. It seems the highly stochastic nature of $M$. vimineum invasions and the small-scale variation within habitats overwhelmed any strong habitat effects. In each habitat, there were some populations which grew rapidly and some which grew slowly or even shrunk. Only two of the reproductive ratios showed significant differences among habitats. It seems likely that the environmental variables which are important for $M$. vimineum success are not necessarily well correlated with our habitat classifications. One important difference that we did observe is that the roadside habitat was the only habitat which led to the establishment of successful 
Table 5 Meta-analysis of parameters and environmental covariates

\begin{tabular}{|c|c|c|c|}
\hline Parameter & Habitat & Estimate & $P$ value \\
\hline$D$ & (Intercept) & & \\
\hline \multirow[t]{2}{*}{ (model $P$ value: $0.0085^{* *}$ ) } & Graminoid cover & -0.0040 & $0.05 *$ \\
\hline & Canopy cover & -0.0043 & $0.00 * *$ \\
\hline$R_{2004}$ & (Intercept) & 1.86 & \\
\hline \multirow[t]{2}{*}{ (model $P$ value: $0.05^{*}$ ) } & Soil moisture & -8.09 & $0.09 * * *$ \\
\hline & Vegetative cover & 0.037 & $0.02 *$ \\
\hline$R_{2005}$ & (Intercept) & 5.00 & \\
\hline \multirow[t]{5}{*}{ (model $P$ value: $0.0000035^{* *}$ ) } & Soil moisture & -0.22 & $0.00 * *$ \\
\hline & Canopy cover & -.056 & $0.00 * *$ \\
\hline & Soil ammonium & 0.24 & $0.00 * *$ \\
\hline & Soil phosphorus & 0.029 & $0.05^{*}$ \\
\hline & Soil calcium & 0.0012 & $0.00 * *$ \\
\hline$R_{2006}$ & (Intercept) & -18.5 & \\
\hline \multirow[t]{4}{*}{ (model $P$ value: $0.000013 * *$ ) } & Canopy cover & -0.082 & $0.00 * *$ \\
\hline & Vegetative cover & -0.12 & $0.00 * *$ \\
\hline & Soil ammonium & 0.26 & $0.00 * *$ \\
\hline & Soil pH & 6.5 & $0.00 * *$ \\
\hline
\end{tabular}

The results of the analysis of parameters by environmental covariates are described. Patches IF1, IF7 and IF10 were again excluded from the analysis due to a lack of standard errors (leaving 7/10 intact forest patches in the analysis), and patch RS2 was excluded because the estimate for $R_{2006}$ is an outlier (leaving $4 / 5$ roadside patches in the analysis)

* Significance of $P \leq 0.05$

** Significance of $P \leq 0.01$

*** Marginal significance $(P \leq 0.10)$

satellite populations, in two of five patches. Such stratified diffusion is thought to explain the spread of invasive goldenrods in Europe (Weber 1998) as well as gypsy moth and other insect pest invasions (Liebhold et al. 1992; Petit et al. 2008). We would conclude that $M$. vimineum can be a problem in any habitat, although not every patch is necessarily problematic. Managers thus must consider that any habitat has the potential to foster rapid growth of this species.

Microstegium vimineum would be a much less harmful invasive species if it only spread through its own natural dispersal, as demonstrated here. It does appear that the potential for spread is greatest along roadsides, as the largest diffusion coefficients were observed in this habitat. M. vimineum has been shown to be associated with roads (Christen and Matlack 2009; Mortensen et al. 2009; Peskin 2005). An association between proximity to roads and occurrence of invasive plants in general has been noted in the literature (Maheu-Giroux and de Blois 2007; Parendes and Jones 2000; Trombulak and Frissell 2000); however, few of these studies have explicitly studied the unpaved roads common in forested areas (but see Watkins et al. 2003). Certainly roads are important in facilitating invasion by serving as corridors for dispersal as well as creating suitable habitat (Parendes and Jones 2000; Trombulak and Frissell 2000; Watkins et al. 2003). We have observed road maintenance equipment, such as road grading on unpaved roads, to be a likely mechanism for road-mediated spread. Water movement is also likely an important vector of spread, as seeds can be carried by water (Mehrhoff 2000). Previous work documented high abundances of $M$. vimineum at the outflow of culverts that undercut the forest roads (Jones and Mortensen 2004), a likely mechanism of movement into the forest interior. It is essential for managers to incorporate the effects of roads and road maintenance when managing invasive plant problems (Mortensen et al. 2009).

The variation in the dispersal and reproductive parameters did not seem to be driven by one particular environmental variable (Table 5). Rather, conditions generally favorable for plants, such as higher nutrient availability and more light (from less 

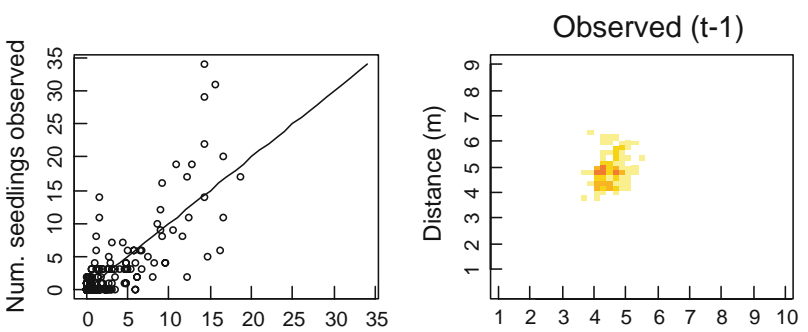

DF3
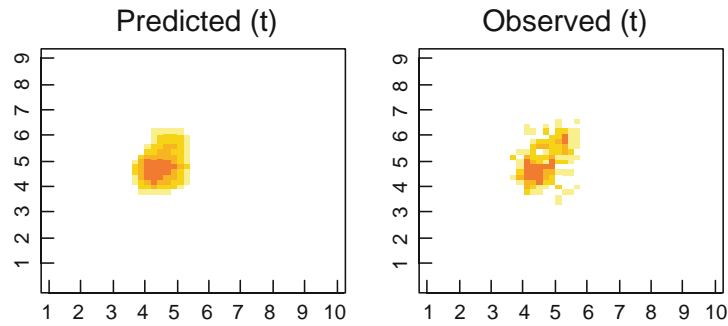

RS4
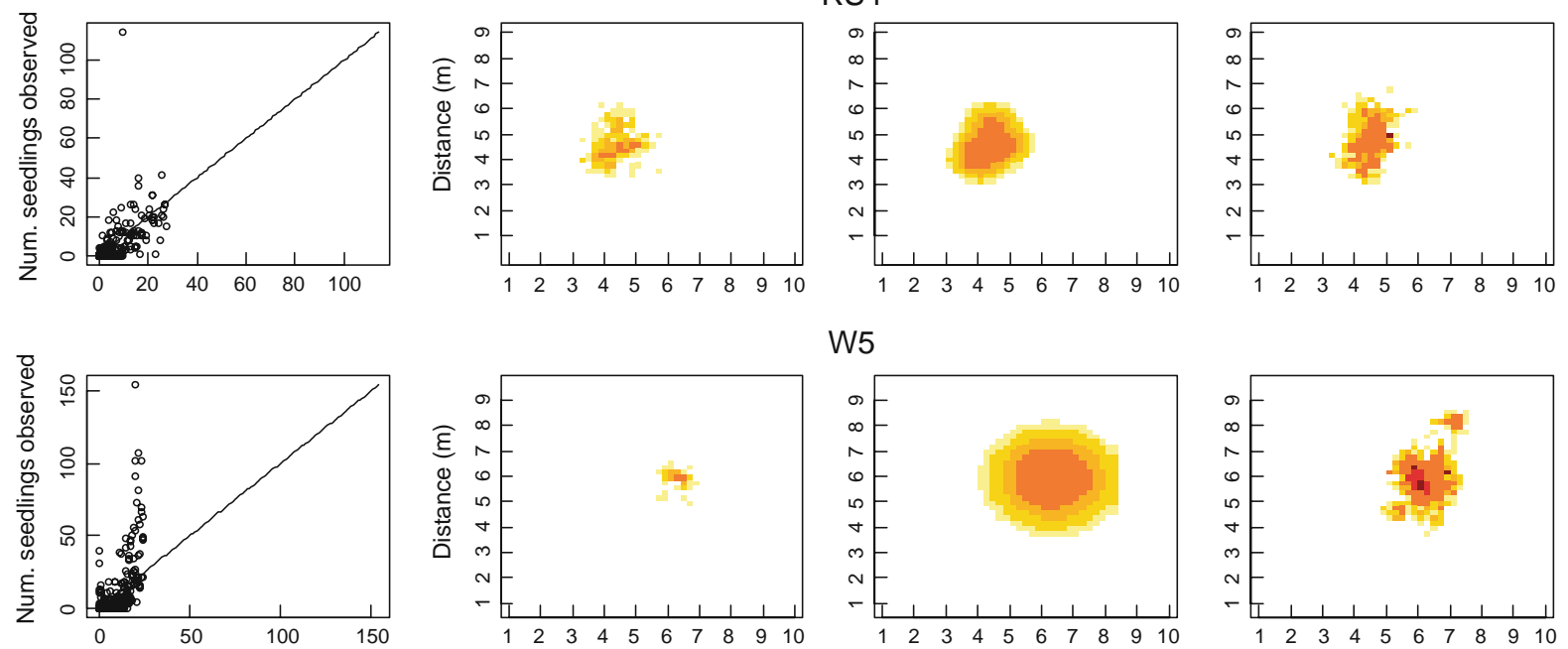

W5
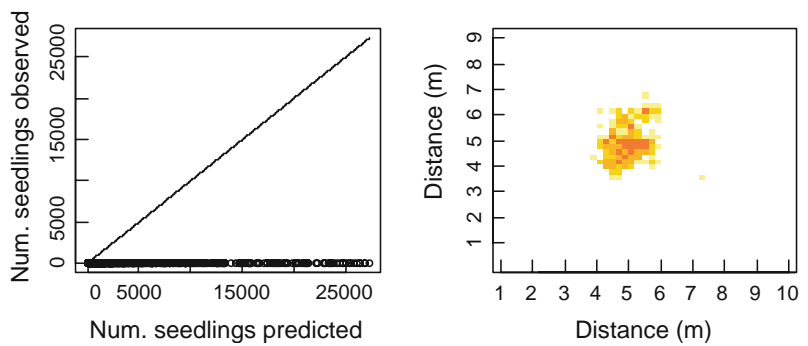

Fig. 4 Sample model predictions. The left panels show plots of observed versus predicted values for the models. The next panels describe what was observed at the previous time step, while the next panel shows the predicted value. The panel to the right shows what actually was observed at the next time
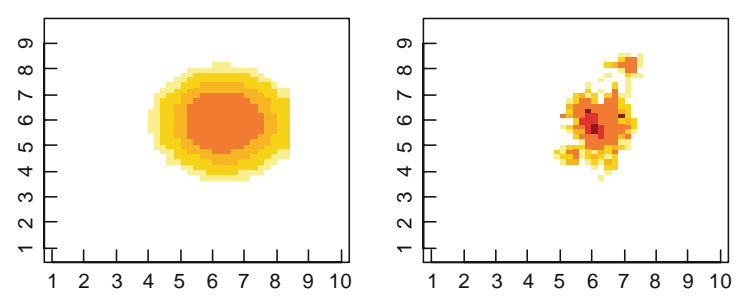

RS2
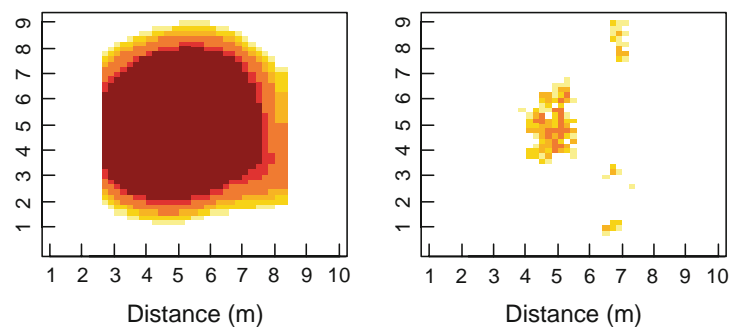

step, for comparison. The upper two rows show patches where the model was fairly successful at describing the population trajectory. The model does not perform as well when expansion is not uniform in all directions (W5) or where satellite populations were established (RS2)

canopy cover) seemed to favor higher reproductive and dispersal abilities. An increase in canopy cover has been associated with a decrease in percent cover and average stem length of $M$. vimineum (Marshall and Buckley 2008a). In contrast to this, Cheplick (2008) found that total dry mass was higher from shady forest interior sites than edges, and vegetative mass was positively associated with reproductive mass. The negative relationship with soil moisture

was more unexpected; it appears that some patches were too wet for favorable growth. M. vimineum has typically been shown to grow poorly when soil moisture is low (Webster et al. 2008; Williams 1998). The relationship with other plant cover was less clear (positive in some instances with increasing vegetative cover in the plot but negative in others); it is possible that earlier in the experiment, having an environment that is generally favorable for all plants was more 
influential than any competition faced by the presence of other plants. Perhaps later in the experiment, competition with other vegetation in the plots became more pronounced as densities increased. M. vimineum's ability to compete with native grasses may be mediated by light availability, with $M$. vimineum more competitive than native grasses in full shade (Flory et al. 2007).

Despite a general trend for increasing growth, there were considerable fluctuations in annual patch performance. Within any given patch, there was generally considerable variation in trajectory. Several patches, such as IF3 and W2, actually shrunk in spatial extent and population size. A few patches, such as W5, stagnated and even decreased in size, and then suddenly exploded in population size. We hypothesize that this occurred due to a change in moisture conditions after spring in 2005; a previously extremely wet area became more suitable for growth in that extremely dry year. We also observed a sudden increase in $M$. vimineum following the formation of a light gap over one patch. Both of these observations are consistent with fluctuating resource theory (Davis et al. 2000), which postulates that any increase in available resources, whether from an increase in supply or a decrease in resource uptake, makes a community more invasible.

Part of the value in studying the trajectories of so many populations is that we were able to gain insight into the conditions under which our modeling approach is less successful at describing the dynamics. The modeling approach used here, using spatial models of plant recruitment calibrated through maximum likelihood methods, was first developed by Ribbens et al. (1994). The model that this approach is based on works well for patches which expand uniformly in all directions and performed well for most patches studied. But it appears that these spatial models used do not work well under some conditions, for example when patches are shrinking. The formation of satellite populations (i.e., stratified diffusion) is also problematic for the model; however, after the first year of establishment, the subsequent expansion of satellite populations can be accommodated easily. The outlier patch in the roadside, RS2, had satellite populations forming between 2005 and 2006; this led to the extremely high reproductive ratio estimated. Because this estimate was an artifact of the model rather than a realistic estimate of the reproductive ratio, this patch was excluded from further analyses. The model assumes that each cell is similarly suitable; it appears that there are likely strong small-scale variations in habitat suitability that can profoundly influence the success of seedlings.

An additional value of this study is it provides insight that can shape integrated management of invasive problems in general and $M$. vimineum in particular. One important insight relates to monitoring programs. Certainly it is clear that monitoring populations only once may not give a clear picture of the invasion potential of a population (Rew et al. 2008); however, it appears that monitoring may be necessary for more than just a few years. There were several populations that we initially believed were moving to extirpation only to rebound later. There may be many invasive species which are able to persist at low abundances for a number of years and then exploit a change in environmental conditions; this may be part of the lag time observed with many species. For example, a long-term study of $R$. multiflora in abandoned fields found that populations only expanded rapidly after the habitat became more favorable for the birds that dispersed the seeds (Banasiak and Meiners 2009). The Brazilian peppertree Schinus terebinthifolius, after persisting at low levels for more than 50 years, became invasive most likely due to a change in water regime in Florida (Ewel 1986). The longer a patch can persist, the more likely that it will experience a window of time favoring rapid population growth. It is also clear that roadside and wetland meadows had the highest likelihood of supporting "super-spreader" patches. By their nature, both habitat types support high recruitment and greater dispersal distances, functionally serving as propagule sources. Given the high efficacy of a number of mechanical and herbicidal options for M. vimineum suppression (Judge et al. 2008; Peskin et al. 2005), site-specific management targeting "hot spots" and thereby eliminating source populations should be a high management priority for this species. Finally, given the short natural dispersal distances observed herein, greater attention should be paid to human mediated dispersal. Limiting dispersal into waterways and during road maintenance as well as unintentional introductions on logging equipment would greatly constrain the spread of this species.

Our study of $M$. vimineum, involving the experiment and modeling approach presented, gives insight 
into the early dynamics of weedy plant invasions. While there is a tendency to view invasive species as highly successful, it appears that there is considerable variation in their success in different habitats and in different years. Some species considered "highly invasive" may in reality be rather poor dispersers in the absence of human activities. In these cases a focus on mechanisms of anthropogenic dispersal is critical to limiting their spread. Careful evaluation of activities that move propagules, such as road maintenance, could prove very effective in slowing the spread of $M$. vimineum and other invasives.

Acknowledgments We wish to thank Brian Jones, Matt Booher, Stephen Kinneer and Daniel Heggenstaller for assistance with fieldwork and Scott Harkcom for access to field sites. Three anonymous reviewers offered helpful comments. This work was partially supported by the National Research Initiative of the USDA-CSREES, grant number 2007-02917.

\section{References}

Adams SN, Engelhardt KAM, Tessel SM (2006) Microstegium vimineum (Japanese Stiltgrass) impacts native diversity above threshold abundance. 91st Annual Meeting of the Ecological Society of America

Androw DA, Kareiva PM, Levin SA, Okubo A (1990) Spread of invading organisms. Landscape Ecol 4:177-188. doi: 10.1007/BF00132860

Baiser B, Lockwood JL, La Puma D, Aronson MFJ (2008) A perfect storm: two ecosystem engineers interact to degrade deciduous forests of New Jersey. Biol Invasions 10:785-795. doi:10.1007/s10530-008-9247-9

Banasiak SE, Meiners SJ (2009) Long term dynamics of Rosa multiflora in a successional system. Biol Invasions 11:215-224. doi:10.1007/s10530-008-9226-1

Barden LS (1987) Invasion of Microstegium vimineum (Poaceae), an exotic, annual, shade-tolerant, C-4 grass, into a North-Carolina floodplain. Am Midl Nat 118:40-45. doi: $10.2307 / 2425626$

Bolker B (2008) Ecological models and data in R. Princeton University Press, Princeton

Braker WL (1981) Soil Survey of Centre County, Pennsylvania. In: United States Department of Agriculture SCS, in cooperation with the Pennsylvania State University College of Agriculture and the Pennsylvania Department of Environmental Resources, State Conservation Commission (ed)

Buckley YM, Brockerhoff E, Langer L, Ledgard N, North H, Rees M (2005) Slowing down a pine invasion despite uncertainty in demography and dispersal. J Appl Ecol 42:1020-1030. doi:10.1111/j.1365-2664.2005.01100.x

Burnham KP, Anderson DR (2004) Multimodel inferenceunderstanding AIC and BIC in model selection. Sociol Methods Res 33:261-304. doi:10.1177/0049124104268 644
Case TJ (2000) An illustrated guide to theoretical ecology. Oxford University Press, New York

Cheplick GP (2005) Biomass partitioning and reproductive allocation in the invasive, cleistogamous grass Microstegium vimineum: influence of the light environment. J Torrey Bot Soc 132:214-224. doi:10.3159/1095-5674 (2005)132[214:BPARAI]2.0.CO;2

Cheplick GP (2007) Plasticity of chasmogamous and cleistogamous reproductive allocation in grasses. Aliso 23:286-294

Cheplick GP (2008) Growth trajectories and size-dependent reproduction in the highly invasive grass Microstegium vimineum. Biol Invasions 10:761-770. doi:10.1007/ s10530-007-9170-5

Christen DC, Matlack GR (2009) The habitat and conduit functions of roads in the spread of three invasive plant species. Biol Invasions 11:453-465. doi:10.1007/s10530008-9262-x

Cole PG, Weltzin JF (2004) Environmental correlates of the distribution and abundance of Microstegium vimineum, in east Tennessee. Southeast Nat 3:545-562. doi:10.1656/ 1528-7092(2004)003[0545:ECOTDA]2.0.CO;2

Cole PG, Weltzin JF (2005) Light limitation creates patchy distribution of an invasive grass in eastern deciduous forests. Biol Invasions 7:477-488. doi:10.1007/s10530004-5171-9

Davis MA, Pelsor M (2001) Experimental support for a resource-based mechanistic model of invasibility. Ecol Lett 4:421-428. doi:10.1046/j.1461-0248.2001.00246.x

Davis MA, Grime JP, Thompson K (2000) Fluctuating resources in plant communities: a general theory of invasibility. J Ecol 88:528-534. doi:10.1046/j.1365-2745. 2000.00473.x

Ehrenfeld JG, Kourtev P, Huang WZ (2001) Changes in soil functions following invasions of exotic understory plants in deciduous forests. Ecol Appl 11:1287-1300. doi: 10.1890/1051-0761(2001)011[1287:CISFFI]2.0.CO;2

Ewel JJ (1986) Invasibility: lessons from South Florida. In: Mooney HA, Drake JA (eds) Ecology of biological invasions of North America and Hawaii. Springer, New York

Fairbrothers DE, Gray JR (1972) Microstegium vimineum (Trin) A-Camus (Gramineae) in United-States. Bull Torrey Bot Club 99:97

Flory SL, Rudgers JA, Clay K (2007) Experimental light treatments affect invasion success and the impact of Microstegium vimineum on the resident community. Nat Areas J 27:124-132

Heilbron DC (1994) Zero-altered and other regression-models for count data with added zeros. Biom J 36:531-547. doi: 10.1002/bimj.4710360505

Horton JL, Neufeld HS (1998) Photosynthetic responses of Microstegium vimineum (Trin.) A. Camus, a shade-tolerant, C-4 grass, to variable light environments. Oecologia 114:11-19. doi:10.1007/s004420050414

Howard JL (2005) Microstegium vimineum in fire effects information system. US Department of Agriculture, Forest Service, Rocky Mountain Research Station, Fire Sciences Laboratory (http://www.fs.fed.us/database/feis/plants/ graminoid/micvim/all.html.). Accessed Febr 2, 2007

Huebner C (2007) Strategic management of five deciduous forest invaders using Microstegium vimineum as a model 
species. Ohio Invasive Plants Research Conference Proceedings: 19-28

Humston R, Mortensen DA, Bjornstad ON (2005) Anthropogenic forcing on the spatial dynamics of an agricultural weed: the case of the common sunflower. J Appl Ecol 42:863-872. doi:10.1111/j.1365-2664.2005.01066.x

Hunt DM, Zaremba RE (1992) The northeastward spread of Microstegium vimineum (Poaceae) into New York and adjacent states. Rhodora 94:167-170

Jacquemyn H, Brys R, Neubert MG (2005) Fire increases invasive spread of Molinia caerulea mainly through changes in demographic parameters. Ecol Appl 15:20972108. doi:10.1890/04-1762

Jones BP, Mortensen DA (2004) Determining seed dispersal mechanisms for the large-scale invasion dynamics of Japanese stiltgrass (Microstegium vimineum). Abstracts. Weed Science Society of America, Kansas City, MO

Judge CA, Neal JC, Schear TH (2008) Japanese Stiltgrass (Microstegium vimineum) management for restoration of native plant communities. Invasive Plant Sci Manag 1:111-119. doi:10.1614/IPSM-07-011.1

Kourtev PS, Ehrenfeld JG, Huang WZ (1998) Effects of exotic plant species on soil properties in hardwood forests of New Jersey. Water Air Soil Pollut 105:493-501. doi: 10.1023/A:1005037105499

Kourtev PS, Ehrenfeld JG, Haggblom M (2002) Exotic plant species alter the microbial community structure and function in the soil. Ecology 83:3152-3166

Liebhold AM, Halverson JA, Elmes GA (1992) Gypsy moth invasions in North America: a quantitative analysis. J Biogeogr 19:513-520. doi:10.2307/2845770

Lodge DM, Williams S, MacIsaac HJ, Hayes KR, Leung B, Reichard S, Mack RN, Moyle PB, Smith M, Andow DA, Carlton JT, McMichael A (2006) Biological invasions: recommendations for US policy and management. Ecol Appl 16:2035-2054. doi:10.1890/1051-0761(2006)016 [2035:BIRFUP]2.0.CO;2

Lonsdale WM (1999) Global patterns of plant invasions and the concept of invasibility. Ecology 80:1522-1536

Lumley $\mathrm{T}$ (2008) Leaps: regression subset selection (using Fortran code by Alan Miller). Available http://cran.rproject.org/

Maheu-Giroux M, de Blois S (2007) Landscape ecology of Phragmites australis invasion in networks of linear wetlands. Landscape Ecol 22:285-301. doi:10.1007/s10980006-9024-Z

Marshall JM, Buckley DS (2008a) Effects of microsites created by selective harvesting on growth of Microstegium vimineum in a central hardwood forest. For Sci 54:534-542

Marshall JM, Buckley DS (2008b) Influence of litter removal and mineral soil disturbance on the spread of an invasive grass in a Central Hardwood forest. Biol Invasions 10:531-538. doi:10.1007/s10530-007-9149-2

Martin TG, Wintle BA, Rhodes JR, Kuhnert PM, Field SA, Low-Choy SJ, Tyre AJ, Possingham HP (2005) Zero tolerance ecology: improving ecological inference by modelling the source of zero observations. Ecol Lett 8:1235-1246. doi:10.1111/j.1461-0248.2005.00826.x

Marushia RG, Holt JS (2006) The effects of habitat on dispersal patterns of an invasive thistle, Cynara cardunculus.
Biol Invasions 8:577-593. doi:10.1007/s10530-0051601-6

Mehrhoff LJ (2000) Perennial Microstegium vimineum (Poaceae): an apparent misidentification? J Torrey Bot Soc 127:251-254. doi: $10.2307 / 3088762$

Mortensen DA, Rauschert ESJ, Nord AN, Jones BP (2009) The role of roads in plant invasions. Invasive Plant Sci Manag (in review)

Myers JH, Simberloff D, Kuris AM, Carey JR (2000) Eradication revisited: dealing with exotic species. Trends Ecol Evol 15:316-320. doi:10.1016/S0169-5347(00)01914-5

Okubo A (1980) Diffusion and ecological problems: mathematical models. Springer Verlag, Berlin

Oswalt CM, Clatterbuck WK, Oswalt SN, Houston AE, Schlarbaum SE (2004) First-year effects of Microstegium vimineum and early growing season herbivory on planted high-quality oak (Quercus spp.) seedlings in Tennessee. Proceedings of the 14th Central Hardwoods Forest Conference, pp 1-9

Oswalt CM, Oswalt SN, Clatterbuck WK (2007) Effects of Microstegium vimineum (Trin.) A. Camus on native woody species density and diversity in a productive mixed-hardwood forest in Tennessee. For Ecol Manag (in press)

Parendes LA, Jones JA (2000) Role of light availability and dispersal in exotic plant invasion along roads and streams in the H. J. Andrews Experimental Forest, Oregon. Conserv Biol 14:64-75. doi:10.1046/j.1523-1739.2000.99089.x

Peskin N (2005) Habitat suitability of Japanese stiltgrass Microstegium vimineum in an Appalacian forest. Master's thesis, Intercollege Graduate Degree Program in Ecology, The Pennsylvania State University, University Park, 136 pp

Peskin N, Mortensen DA, Jones BP, Booher MR (2005) Grassselective herbicides improve diversity of sites infested with Japanese Stiltgrass (Pennsylvania). Ecol Res 23:6465

Petit JN, Hoddle MS, Grandgirard J, Roderick GK, Davies N (2008) Invasion dynamics of the glassy-winged sharpshooter Homalodisca vitripennis (Germar) (Hemiptera : Cicadellidae) in French Polynesia. Biol Invasions 10:955967. doi:10.1007/s10530-007-9172-3

Rew LJ, Lehnhoff EA, Maxell BA (2008) Prioritizing nonindigenous species management using a survey, monitoring and modeling framework. Can J Plant Sci (Accepted for publication 12/2007)

Ribbens E, Silander JA, Pacala SW (1994) Seedling recruitment in forests - calibrating models to predict patterns of tree seedling dispersion. Ecology 75:1794-1806. doi: $10.2307 / 1939638$

Shadel WP, Molofsky J (2002) Habitat and population effects on the germination and early survival of the invasive weed, Lythrum salicaria L. (purple loosestrife). Biol Invasions 4:413-423. doi:10.1023/A:1023668918643

Sharov AA, Leonard D, Liebhold AM, Roberts EA, Dickerson W (2002) "Slow the Spread": a national program to contain the gypsy moth. J For 100:30-35

Sutton JR, Stohlgren TJ, Beck KG (2007) Predicting yellow toadflax infestations in the Flat Tops Wilderness of Colorado. Biol Invasions 9:783-793. doi:10.1007/s10530006-9075-8 
R Development Core Team (2008) R: a language and environment for statistical computing. $\mathrm{R}$ Foundation for Statistical Computing, Vienna, Austria. ISBN 3-90005107-0, URL http://www.R-project.org

The Pennsylvania State Climatologist (2007) (http://climate. met.psu.edu/data/state.php). Accessed March 8, 2007

The Pennsylvania State University Automated Weather Observation System (2007) The Pennsylvania State University Automated Weather Observation System at Rock Springs, PA. (http://www.meteo.psu.edu/ syrett/monthsum.htm). Accessed March 8, 2007

Trombulak SC, Frissell CA (2000) Review of ecological effects of roads on terrestrial and aquatic communities. Conserv Biol 14:18-30. doi:10.1046/j.1523-1739.2000. 99084.x

Tu M (2000) Element Stewardship Abstract for Microstegium vimineum (http://tncweeds.ucdavis.edu/esadocs/documnts/ micrvim.pdf). Accessed Febr 1, 2007, pp 1-8

USDA-NRCS (2007) The PLANTS database (http://plants. usda.gov.). Accessed 15 Jan 2007

Venables WN, Ripley BD (2002) Modern applied statistics with S. Springer, New York

Virginia Department of Conservation and Recreation NHP (2006) Species factsheet: Japanese stiltgrass (Microstegium vimineum) (http://www.dcr.virginia.gov/natural_heritage/ invspfactsheets.shtml). Accessed Febr 2, 2007

Watkins RZ, Chen JQ, Pickens J, Brosofske KD (2003) Effects of forest roads on understory plants in a managed hardwood landscape. Conserv Biol 17:411-419. doi:10.1046/ j.1523-1739.2003.01285.x

Weber E (1998) The dynamics of plant invasions: a case study of three exotic goldenrod species (Solidago L.) in Europe. J Biogeogr 25:147-154. doi:10.1046/j.1365-2699.1998. 251119.x

Webster CR, Rock JH, Froese RE, Jenkins MA (2008) Drought-herbivory interaction disrupts competitive displacement of native plants by Microstegium vimineum, 10-year results. Oecologia 157:497-508. doi:10.1007/ s00442-008-1085-z

Williams LD (1998) Factors affecting growth and reproduction in the invasive grass Microstegium vimineum. Masters, Biology, Appalachian State University

Winter K, Schmitt MR, Edwards GE (1982) Microstegium vimineum, a shade adapted C-4 grass. Plant Sci Lett 24:311-318. doi:10.1016/0304-4211(82)90027-X 